\title{
Inhibition of Notch pathway prevents osteosarcoma growth by cell cycle regulation
}

\author{
M Tanaka',2, T Setoguchi*, ',2 , M Hirotsu', H Gao', H Sasaki', Y Matsunoshita' and S Komiya' \\ 'Department of Orthopaedic Surgery, Graduate School of Medical and Dental Sciences, Kagoshima University, 8-35-I Sakuragaoka, \\ Kagoshima 890-8520, Japan
}

\begin{abstract}
The study shows constitutive activation of the Notch pathway in various types of malignancies. However, it remains unclear how the Notch pathway is involved in the pathogenesis of osteosarcoma. We investigated the expression of the Notch pathway molecules in osteosarcoma biopsy specimens and examined the effect of Notch pathway inhibition. Real-time PCR revealed overexpression of Notch2, Jagged I, HEYI, and HEY2. On the other hand, Notch I and DLLI were downregulated in biopsy specimens. Notch pathway inhibition using $\gamma$-secretase inhibitor and CBFI siRNA slowed the growth of osteosarcomas in vitro. In addition, $\gamma$-secretase inhibitortreated xenograft models exhibited significantly slower osteosarcoma growth. Cell cycle analysis revealed that $\gamma$-secretase inhibitor promoted GI arrest. Real-time PCR and western blot revealed that $\gamma$-secretase inhibitor reduced the expression of accelerators of the cell cycle, including cyclin DI, cyclin EI, E2, and SKP2. On the other hand, p2 I ${ }^{\text {ip I }}$ protein, a cell cycle suppressor, was upregulated by $\gamma$-secretase inhibitor treatment. These findings suggest that inhibition of Notch pathway suppresses osteosarcoma growth by regulation of cell cycle regulator expression and that the inactivation of the Notch pathway may be a useful approach to the treatment of patients with osteosarcoma.

British Journal of Cancer (2009) I 00, 1957-1965. doi:I0.1038/sj.bjc.6605060 www.bjcancer.com
\end{abstract}

Published online 19 May 2009

(c) 2009 Cancer Research UK

Keywords: osteosarcoma; Notch; cell cycle; $\gamma$-secretase inhibitor; CBFI

Osteosarcoma is the most common primary bone cancer occurring mainly in children (Gibbs et al, 2002). After initial diagnosis is made by biopsy, treatment consists of preoperative chemotherapy, followed by definitive surgery and postoperative chemotherapy. Survival has improved over the past several decades. Indeed, patients with non-metastatic disease have a $70 \%$ chance of long-term survival. Unfortunately, patients with metastatic disease at diagnosis or those who have recurrent disease have a poor prognosis, with only $20 \%$ surviving at 5 years, indicating that new therapeutic options for them need to be actively explored. In cancer cells, dysregulation of cell division and apoptotic processes contribute to drug resistance and to metastatic potential (Igney and Krammer, 2002; Lafleur et al, 2004). It is reported that the cell cycle regulatory pathway centred around $\mathrm{pRb}$ is frequently somatically inactivated in osteosarcomas (Horowitz et al, 1990). Although such dysregulation may represent a potent source of new therapeutic targets, the molecular mechanisms that regulate osteosarcoma cell proliferation are largely unknown.

Members of the Notch family are highly conserved transmembrane receptors that influence the proliferation and apoptosis of diverse types of cells in a variety of organisms (Artavanis-

\footnotetext{
*Correspondence: Dr T Setoguchi;

E-mail: setoro@m2.kufm.kagoshima-u.ac.jp

2 These authors contributed equally to this work

Received 9 January 2009; revised 19 March 2009; accepted 30 March

2009; published online 19 May 2009
}

Tsakonas et al, 1999). Activation of Notch signalling requires binding of its ligands (Jagged, DLL), followed by proteolytic release of the Notch intracellular domain (NIC) and its translocation to the nucleus (De Strooper et al, 1999). Notch intracellular domain interacts with CSL transcription factors (CBF1/RBP-J $\kappa, \mathrm{Su}(\mathrm{H}), \mathrm{Lag}-1)$ and converts them from repressors to activators, promoting transcription of downstream genes involved in various differentiation programmes (Davis and Turner, 2001). Recent studies have also shown constitutive activation of the Notch pathway in various types of malignancies. The oncogenic potential of Notch has been reported in human T-cell acute lymphoblastic leukaemia (Grabher et al, 2006), non-small cell lung cancer (Dang et al, 2000), ovarian carcinomas (Park et al, 2006), and pancreatic cancer (Miyamoto et al, 2003). Although, it was recently reported that DLL1, Notch1, Notch2, and HES1 are expressed in osteosarcoma cell lines, whether expression of Notch signalling molecules in osteosarcoma patient specimens is aberrant has not been clarified.

To explore the involvement of aberrant Notch signalling in the pathogenesis of osteosarcoma, we investigated the expression of the Notch pathway molecules in osteosarcoma patient specimens and examined the effects of Notch pathway inhibition by $\gamma$-secretase inhibitor (GSI) and CBF1 siRNA. We found that Notch2, Jagged1, HEY1, and HEY2 were upregulated in the osteosarcoma biopsy specimens. On the other hand, Notch1 and DLL1 were downregulated in biopsy specimens. In addition, Notch pathway inhibition prevented the growth of osteosarcoma in vitro and in vivo by cell cycle regulation. 


\section{MATERIALS AND METHODS}

\section{Cell culture}

Human osteosarcoma cell lines, HOS, 143B, Saos-2, and U2OS cells were purchased from the American Type Culture Collection (ATCC). Cells were grown in Dulbecco's modified Eagle's medium (DMEM) supplemented with $10 \% \mathrm{FBS}$, penicillin $\left(100 \mathrm{U} \mathrm{ml}^{-1}\right)$, and streptomycin $\left(100 \mu \mathrm{g} \mathrm{ml}^{-1}\right)$. Human osteoblast cells (NHOst) were purchased from Sanko Junyaku (Tokyo, Japan). Cells were cultured with OBM (Cambrex, East Rutherford, NJ, USA) or DMEM supplemented with $10 \%$ FBS. All cells were grown in a humidified atmosphere containing $5 \% \mathrm{CO}_{2}$ at $37^{\circ} \mathrm{C}$.

\section{Patient specimens}

All osteosarcoma biopsy specimens were obtained from primary lesions. Biopsy was carried out before chemo- or radiotherapy to make the diagnosis. Normal bone tissue was obtained from femur during total hip arthroplasty.

\section{Real-time PCR (RT - PCR)}

For real-time PCR (RT-PCR), total RNA was DNase-treated and reverse transcribed using oligo(dT) primers as described by the manufacturer (Invitrogen, Carlsbad, CA, USA). Reactions were run using SYBR Green (BIO-RAD, Hercules, CA, USA) on a MiniOpticon machine (BIO-RAD). The comparative $C_{\mathrm{t}}\left(\Delta \Delta C_{\mathrm{t}}\right)$ method was used to determine fold change in expression using $\beta$ II-microglobulin. Each sample was run minimally at three concentrations in triplicate. All primer sets amplified 100 to $200 \mathrm{bp}$ fragments. The primer sequences used were as follows: for Notch1: 5-GTGACTGCTCCCTCAACTTCAAT-3, 5-CTGTCACAGTGGCCG TCACT-3; Notch2: 5-AAAAATGGGGCCAACCGAGAC-3, 5-TTCA TCCAGAAGGCGCACAA-3; Jagged1: 5-CGGGATTTGGTTAATGG TTATC-3，5-ATAGTCACTGGCACGGTTGTAGCAC-3; DLL1: 5-C CTACTGCACAGAGCCGATCT-3， 5-GCAGGTGGCTCCATTCTTG C-3; HES1: 5-AGGCGGACATTCTGGAAATG-3，5-CGGTACTTC CCCAGCACACTT-3; HEY1: 5-CGAGGTGGAGAAGGAGAGTG-3, 5-CTGGGTACCAGCCTTCTCAG-3; HEY2: 5-GAACAATTACTCG GGGCAAA-3, 5-TCAAAAGCAGTTGGCACAAG-3; CBF1: 5-CGCA TTATTGGATGCAGATG-3, 5-CAGGAAGCGCCATCATTTAT-3; cyclin D1: 5-ACAAACAGATCATCCGCAAACAC-3，5-TGTTGGG GCTCCTCAGGTTC-3; cyclin E1: 5-CCACACCTGACAAAGAAGA TGATGAC-3, 5-GAGCCTCTGGATGGTGCAATAAT-3; cyclin E2: 5-TGTTGGCCACCTGTATTATCTGG-3; 5-ATCTGGAGAAATCAC TTGTTCCTATTTC-3; SKP2: 5-TGGGAATCTTTTCCTGTCTG-3, 5-GAACACTGAGACAGTATGCC-3; c-Myc: 5-GCCACGTCTCCAC ACATCAG-3, 5-TGGTGCATTTTCGGTTGTTG-3; $\beta$ II-microglobulin: 5-TCAATGTCGGATGGATGAAA-3, 5-GTGCTCGCGCTACT CTCTCT-3.

\section{MTT assay}

Cells were incubated with substrate with MTT (3-(4,5-dimethylthiazol-2-yl)-2,5-diphenyltetrazolium bromide) for $4 \mathrm{~h}$, and washed with PBS and lysed to release formazan from cells. Then cells were analysed in a Safire microplate reader (BIO-RAD) at $562 \mathrm{~nm}$. $\gamma$-Secretase inhibitor X was used for MTT assay.

CBF1 siRNA was purchased from Santa Cruz (Santa Cruz, CA, USA). Lipofection of siRNA was carried out every other day as recommended in the supplier's protocol using FuGENE 6 (Roche, Basel, Switzerland).

\section{Cell death detection}

Cell death detection ELISA ${ }^{\text {plus }}$ (Roche) was used to detect cell death as per manufacturer's protocol. Briefly, cells were incubated with different concentrations of camptothecin (CAM) for $4 \mathrm{~h}$ at $37^{\circ} \mathrm{C}$. Before and after lysis, cells were centrifuged and the supernatant was analysed.

\section{Immunohistochemistry}

The following primary antibodies were used: anti-HES1 (diluted 1:200; Chemicon, Temecula, CA, USA) and ki67 (Zymed Laboratories, San Francisco, CA, USA). The following secondary antibodies were used; fluorescein rhodamine-conjugated donkey antirabbit IgG antibody (diluted 1:200; Chemicon). The cells were counterstained with Hoechst 33258 (Molecular Probes, Carlsbad, CA, USA) to identify nuclei. Immunohistochemistry with each second antibody alone without primary antibody was carried out as a control.

\section{Western blot}

Cells were lysed using NP40 lysis buffer $(0.5 \%$ NP40, $10 \mathrm{~mm}$ Tris$\mathrm{HCl}$ (pH 7.4), $150 \mathrm{~mm} \mathrm{NaCl}, 3 \mathrm{~mm}$ pAPMSF (Wako Chemicals, Kanagawa, Japan), $5 \mathrm{mg} \mathrm{ml}^{-1}$ aprotinine (Sigma, St Louis, MO, USA), $2 \mathrm{~mm}$ sodium orthovanadate (Wako Chemicals), and $5 \mathrm{~mm}$ EDTA). Lysates were subjected to SDS-PAGE and subsequent immunoblotting with antibodies to actin, cyclin D1, E1, E2, p21, SKP2, pRb, c-Myc (Santa Cruz), and Notch2-inter cellular domain (Abcam, Cambridge, UK). Detection was carried out using the ECL detection system (Amersham, Chalfont St Giles, UK).

\section{Animal experiments}

In all, $143 \mathrm{~B}$ cells $\left(1 \times 10^{6}\right)$ were mixed with collagen gel in a $1: 1$ volume, and inoculated subcutaneously in 5-week-old nude mice. The mice were randomly assigned to receive either GSI XX (10 $\mu \mathrm{g} \mathrm{kg}^{-1}$; CALBIOCHEM, Basel, Switzerland) or an equal volume of physiological saline solution (control). $\gamma$-Secretase inhibitor XX and saline solution were administered by intraperitoneal injection. The treatment with GSI XX was initiated 1 week after tumour inoculation when the tumours had grown to visible size. Tumour size was measured with calipers weekly, and tumour volume was calculated using the formula $\mathrm{LW}^{2} / 2$ (with $\mathrm{L}$ and $\mathrm{W}$ representing the length and width of tumours). All experimental procedures were carried out in compliance with the guiding principles for the Care and Use of Animals described in the American Journal of Physiology and with the Guidelines established by the Institute of Laboratory Animal Sciences, Faculty of Medicine, Kagoshima University. All efforts were made to minimise animal suffering, to reduce the number of animals used, and to utilise possible alternatives to in vivo techniques.

\section{Cell cycle analysis}

Cell cycle analysis was committed and carried out by Reprocell (Tokyo, Japan). At $48 \mathrm{~h}$ after GSI X treatments, cells were collected

Figure I Notch pathway molecules are overexpressed in osteosarcoma patient specimens. Total RNA extracted from osteosarcoma biopsy specimens was used for real-time PCR. Ten of ten human biopsy specimens of osteosarcoma increased Notch2 1.3-57.3-fold. Notchl was decreased 0.03-0.86-fold in 9 of 10 biopsy specimens. Jagged I was upregulated 3.6-309-fold in 10 of 10 biopsy specimens. In 9 of I 0 human biopsy specimens, DLLI was decreased $0.02-0.35$-fold. HESI was upregulated in 6 of 10 and downregulated in 4 of 10 biopsy specimens. HEYI was upregulated $1.6-12$-fold in 8 of 10 biopsy specimens. HEY2 was upregulated 2.9 - 106-fold in 9 of 10 biopsy specimens. The comparative $C_{t}\left(\Delta \Delta C_{t}\right)$ method was used to determine fold change in expression using $\beta \|$-microglobulin. Each sample was run minimally at three concentrations in triplicate. 
by trypsinisation and washed with DPBS. Cells were fixed in $70 \%$ (v/v) ethanol at $4{ }^{\circ} \mathrm{C}$, washed with PBS, and resuspended with $500 \mu \mathrm{l}$ of staining solution (PBS pH 7.4, $100 \mu \mathrm{g} \mathrm{ml}^{-1}$ DNase-free RNase,
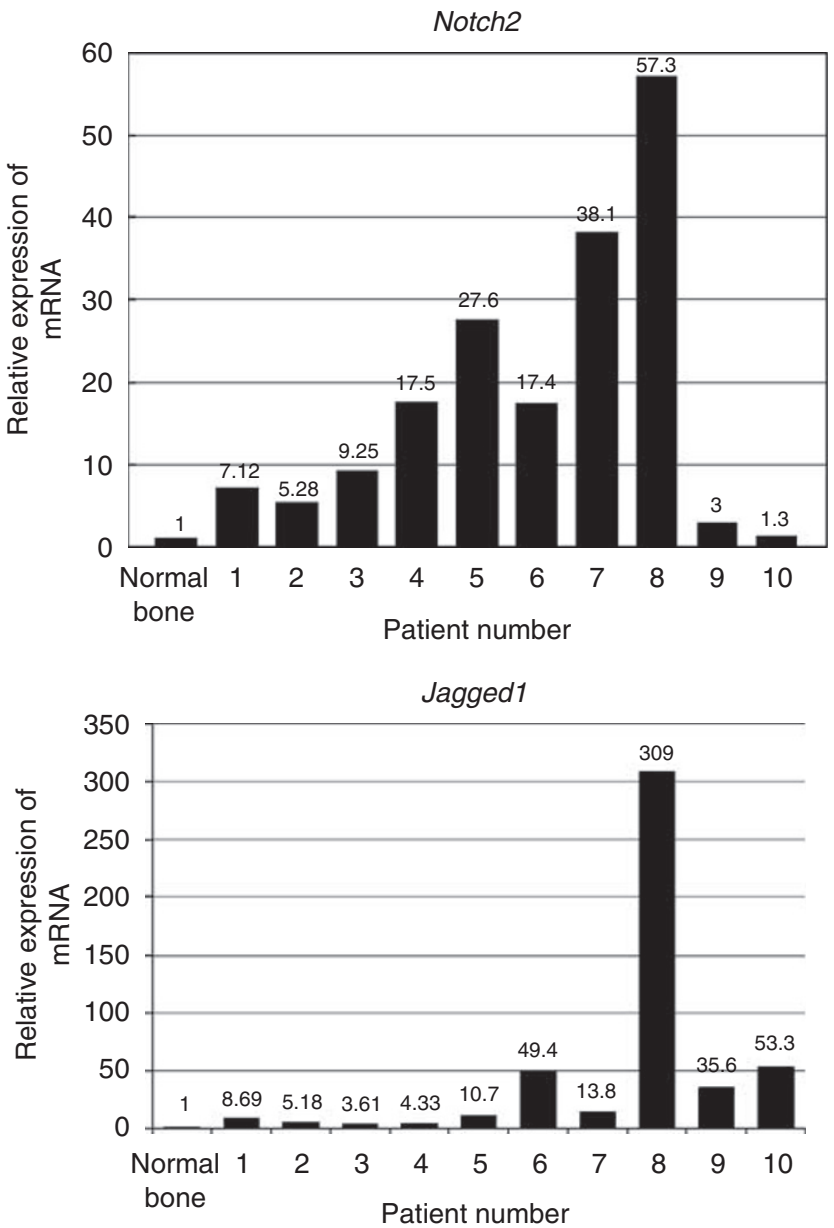

$H E Y 1$

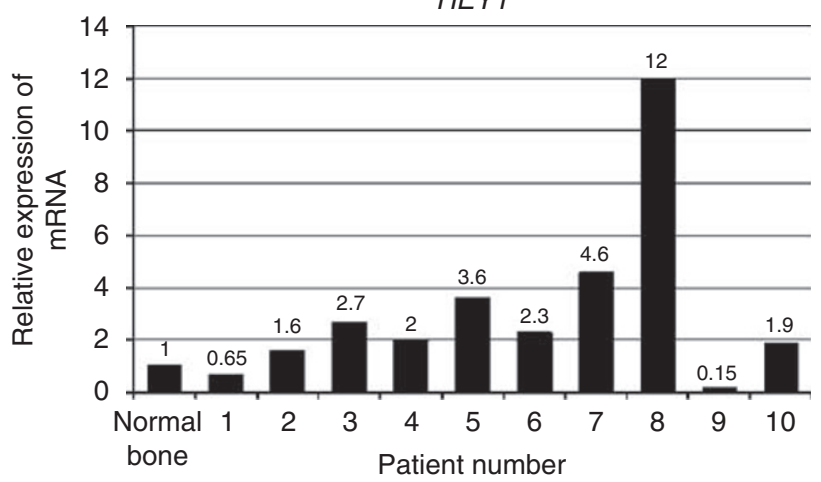

$1 \mathrm{mg} \mathrm{ml}^{-1}$ propidium iodide). Cells were then analysed by flow cytometry using an FACS Vantage SE (Becton Dickinson, Franklin Lakes, NJ, USA). Data were gated using pulse width and pulse
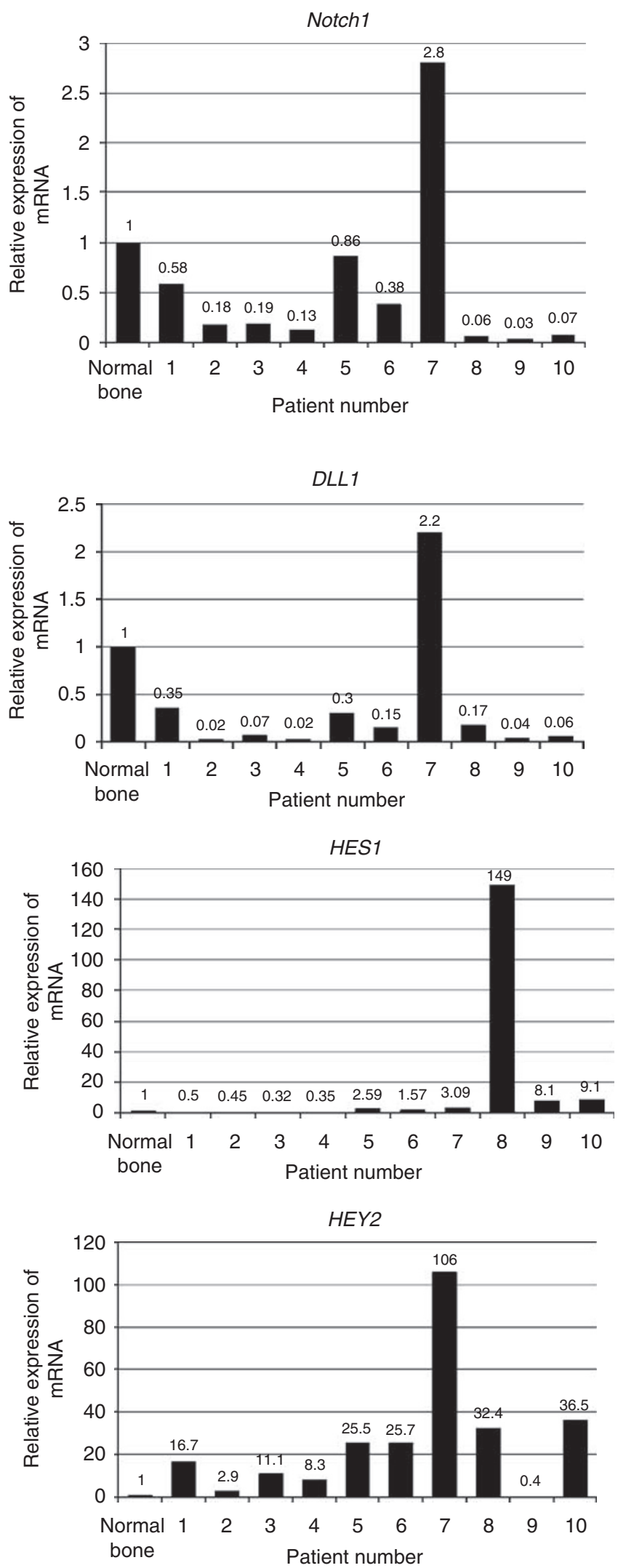
area to exclude doublets, and the percent of cells present in each phase of the cell cycle was calculated using FlowJo software (Tree Star, Ashland, OR, USA).

\section{Statistics}

Each sample was analysed in triplicate, and experiments were repeated three times. In all figures, error bars are s.d. All statistical analyses were carried out using Microsoft Office Excel (Microsoft, Albuquerque, New Mexico, USA) and STASTISCA (StatSoft, Tulsa, OK, USA). Differences between mean values were evaluated by the unpaired $t$-test, and differences in frequencies were evaluated by Fisher's exact test. Differences were considered significant at $P<0.05$.

\section{RESULTS}

\section{Notch2, Jagged1, HEY1, and HEY2 are overexpressed in osteosarcoma patient specimens}

Real-time PCR was carried out to examine the gene expression of Notch pathway molecules. Real-time PCR revealed that 10 of 10 human biopsy specimens of osteosarcoma increased Notch2 1.357.3-fold (Figure 1). On the other hand, Notch1 was decreased $0.03-0.86$-fold in 9 of 10 human biopsy specimens (Figure 1). To further examine Notch pathway molecules expression, we carried out RT-PCR for Notch ligands and Notch target genes. It was reported that Jagged1 and DLL1 are Notch ligands (Bettenhausen et al, 1995; Oda et al, 1997). Jagged 1 was upregulated 3.6-309-fold in 10 of 10 human biopsy specimens of osteosarcoma (Figure 1). On the other hand, DLL1 was decreased 0.02-0.35-fold in 9 of 10 human biopsy specimens (Figure 1). It was reported that HES and $H E Y$ are Notch target genes (Jarriault et al, 1995; Maier and Gessler, 2000). HES1 was upregulated in 6 of 10 and downregulated in 4 of 10 biopsy specimens (Figure 1). HEY1 was upregulated 1.6-12-fold in 8 of 10 human biopsy specimens (Figure 1). HEY2 was upregulated 2.9-106-fold in 9 of 10 human biopsy specimens (Figure 1). Immunohistochemical examination revealed that HES1 was accumulated in the nuclei of human osteosarcoma samples (Supplementary data A). These findings suggest that the Notch signalling pathway is activated in human osteosarcomas.

\section{Inhibition of Notch pathway prevents osteosarcoma growth in vitro and in vivo}

To determine whether Notch pathway activation is required for osteosarcoma cell growth and survival, we used GSI X, a pharmacological agent known to effectively block Notch activation by inhibiting the proteolysis and translocation of NIC to the nucleus. We carried out RT-PCR to determine which concentration of GSI X effectively inhibited Notch activity in osteosarcoma cells, and then measured the expression of the Notch pathway target HES1. In $143 \mathrm{~B}$ cell, GSI X at $5 \mu \mathrm{M}$ reduced mRNA levels of HES1 in 143B cells more than 60\% (Figure 2A). As GSI-18 was used to prevent glioma cell growth at $2-10 \mu \mathrm{M}$ (Fan et al, 2006), we decided that $5 \mu \mathrm{M}$ was appropriate concentration for osteosarcoma. In addition, western blot showed that $5 \mu \mathrm{M}$ GSI X decreased the Notch2-inter cellular domain (Figure 2B). These data suggest that Notch signalling is blocked as expected with GSI. We then assessed the tumour growth in vitro under GSI treatment. MTT assay revealed that GSI treatment slowed the growth of HOS and 143B in dose-dependent fashion, suggesting that this concentration is sufficient to induce the antitumour effect mediated by GSI (Figure 2C). On the other hand, cell death detection assay revealed that GSI did not affect cell death (Supplementary data B). To confirm the effects of Notch pathway inhibition, we examined those of $C B F 1$ siRNA. When NIC translocates to the nucleus, it binds CBF1 and activates transcription of target genes. Real-time PCR revealed that siRNA effectively knocked down $C B F 1$ mRNA (Figure 2D). MTT assay revealed that viable cell mass was reduced by $C B F 1$ siRNA in HOS and $143 \mathrm{~B}$ (Figure 2E). We next examined the effects of Notch pathway blockade on tumour formation in vivo. Nude mice were inoculated with 143B osteosarcoma cells intradermally, and palpable tumours formed in 7 days. The mice were then injected intraperitoneally in GSI or DMSO as a control as reported earlier (van Es et al, 2005). The injections were repeated every other day. Results showed significant inhibition of tumour growth in the GSI-treated vs DMSO-treated control group. All of the 6 GSI-treated tumours exhibited significantly slower growth than DMSO-treated tumours (Figure $3 \mathrm{~A}$ and $\mathrm{B}$ ). Kaplan-Meier analysis showed that GSI administration conferred a significant survival benefit (Figure 3C). Histological analysis indicated that GSI induced growth arrest. The control tumours exhibited a number of cells positive for Ki67, a marker of cell proliferation. In contrast, GSI-treated tumours exhibited little evidence of proliferation, as evidenced by lack of Ki67 positivity. The number of Ki67-positive cells was decreased to $36 \%$ of control level by GSI administration (Figure 3D).

\section{Notch pathway regulates osteosarcoma cell cycle}

We examined cell cycle characteristics by flow cytometry. When HOS cells were cultured without GSI, $54.6 \%$ of cells were in G1 phase. On the other hand, when cultured with GSI, $64.8 \%$ of cells were in G1 phase. In the case of 143B cells cultured without GSI, $39.8 \%$ of cells were in G1 phase, whereas $53.3 \%$ of cells were in G1 phase when treated with GSI (Figure 4A). These findings suggested that GSI promoted G1 arrest. We then examined the transcription of genes related to the cell cycle. Real-time PCR revealed that GSI prevented the transcription of accelerators of the cell cycle, including cyclin $D$, cyclin E1, cyclin E2, SKP2, and $c-M y c$ (Figure 4B). In mammalian cells, cyclin $\mathrm{D}$, cyclin $\mathrm{E}$, and $\mathrm{p} 21^{\mathrm{cip} 1}$ are short-lived proteins that are controlled by ubiquitin-dependent proteolysis. Western blot examination showed that GSI reduced the levels of expression of cyclin E1, cyclin E2, c-Myc, p-Rb, and SKP2 proteins. We next examined the expression of $\mathrm{p} 21^{\text {cip } 1}$, and found that $\mathrm{p} 21^{\mathrm{cip} 1}$ protein was upregulated by GSI treatment (Figure 4C). These findings suggested that GSI promoted G1 arrest by inhibition of G1-S phase progression.

\section{DISCUSSION}

Deregulation of Notch signalling is implicated in the development of various cancers, and Notch blockade appears to affect the survival and proliferation of multiple types of cancer (Radtke and Raj, 2003; Politi et al, 2004; Weng and Aster, 2004). For example, Notch is activated by translocation or mutation in more than half of T-cell acute lymphoblastic leukaemias, and anti-Notch treatments have been shown to slow the growth of acute lymphoblastic leukaemia growth in vitro (Weng et al, 2004). In addition, combining GSIs and anticancer drugs improve anticancer effect (Meng et al, 2009; Real et al, 2009). In this study, we found that Notch2, Jagged1, HEY1, and HEY2 were overexpressed in human osteosarcoma specimens. On the other hand, expression of Notch1 and DLL1 was downregulated in biopsy specimens. Recently, Zhang et al (2008) reported that osteosarcoma cell lines, including OS187, COL, SAOS2, and LM7, expressed Notch-related molecules. Real-time PCR revealed that Notch1 expression was upregulated in three of four cell lines. Notch2 expression was upregulated in two of four cell lines, and HES1 expression was upregulated in two of four cell lines. These results suggested that expression of Notch-related genes differs markedly among cell lines and patient specimens. Zhang et al (2008) carried out RT-PCR for two osteosarcoma patient specimens and found that both expressed Notch1, Notch2, Notch4, HES1, and HERP2 mRNA, although they did not present RT-PCR data. We also carried out RT-PCR using osteosarcoma biopsy specimens and detected the PCR 
A

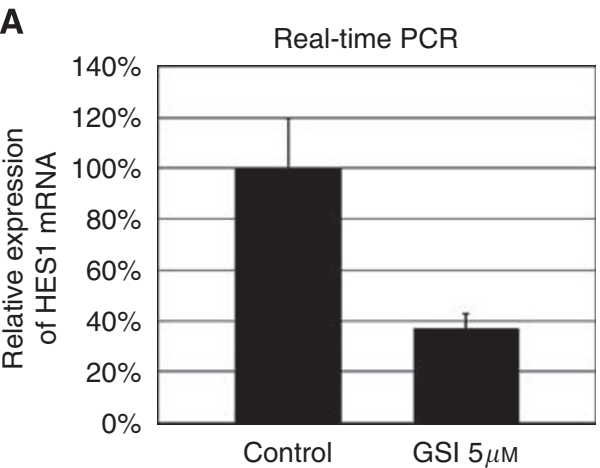

C

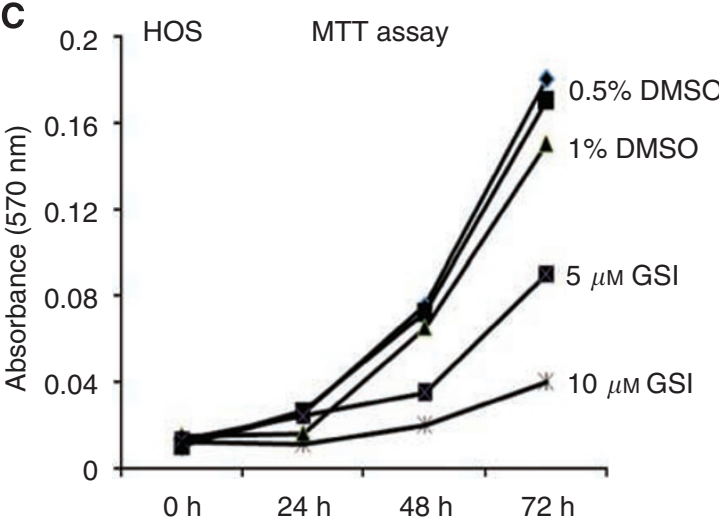

B
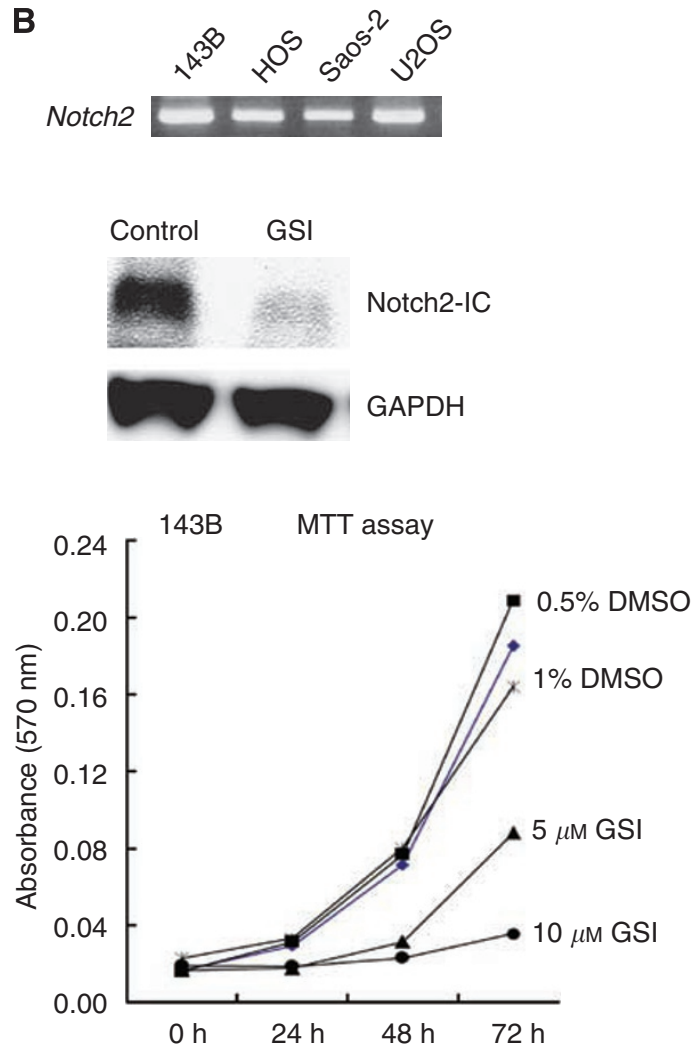
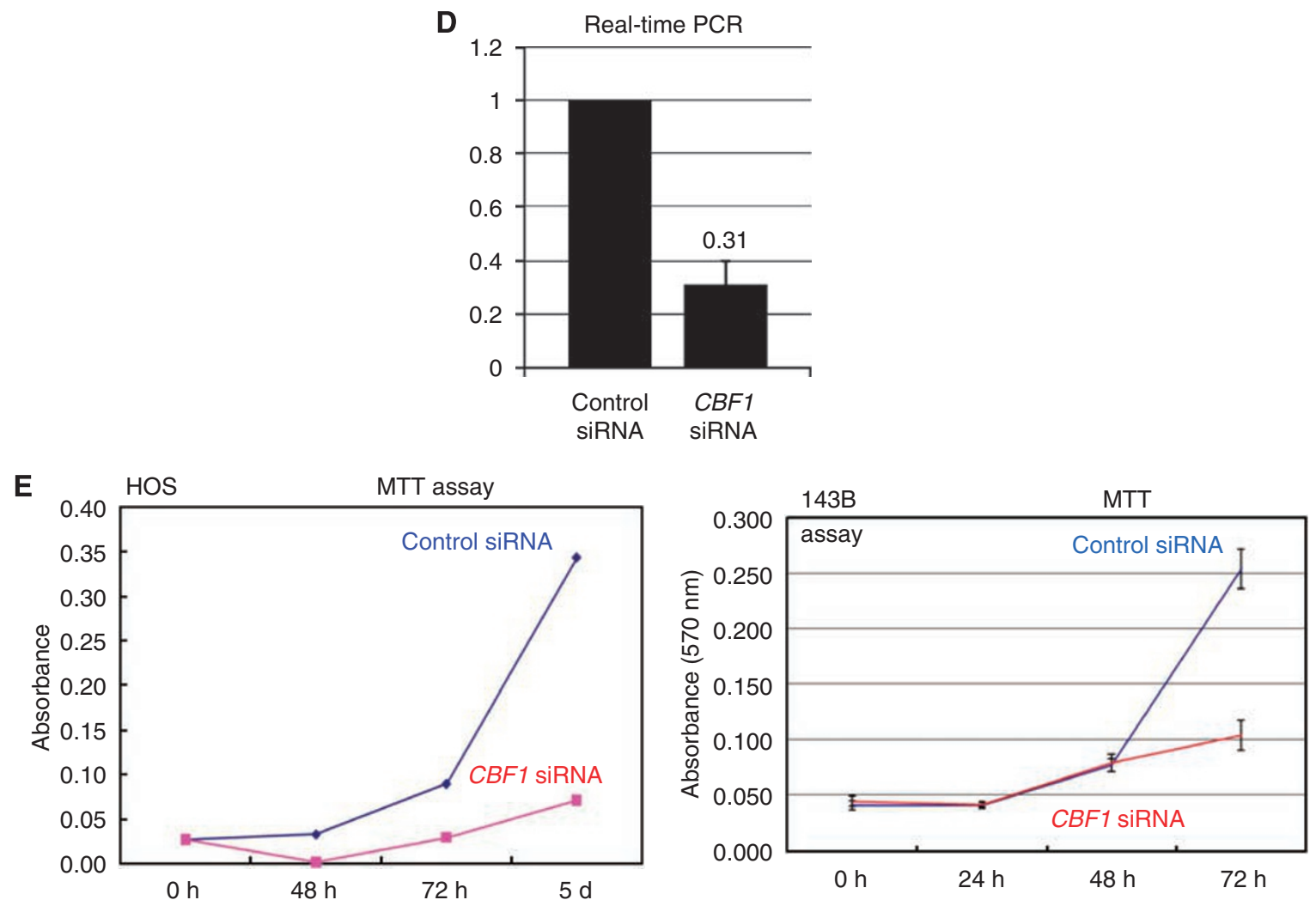

Figure 2 Inhibition of Notch pathway prevents proliferation of osteosarcoma in vitro. Real-time PCR revealed four human osteosarcoma cell lines that express Notch2 (B). We carried out RT-PCR to determine which concentration of $\gamma$-Secretase inhibitor (GSI) X effectively inhibited Notch activity in osteosarcoma cells, and then measured the expression of the Notch pathway target HESI. $\gamma$-Secretase inhibitor X at $5 \mu$ M reduced mRNA levels of HESI in I43B cells more than 60\% (error bar means s.d.) (A). Western blot analysis showed that $5 \mu \mathrm{M}$ GSI treatment reduced Notch2 intercellular domain (B). Growth of viable HOS and I 43B cells over 3 days was slowed in dose-dependent fashion by GSI X (C). Real-time PCR revealed that siRNA knocked down CBFI mRNA about 69\% (D). Growth of HOS and I43B cells was slowed by CBFI siRNA (E). 
A

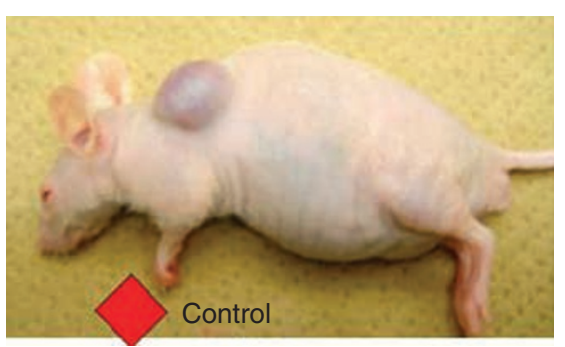

B

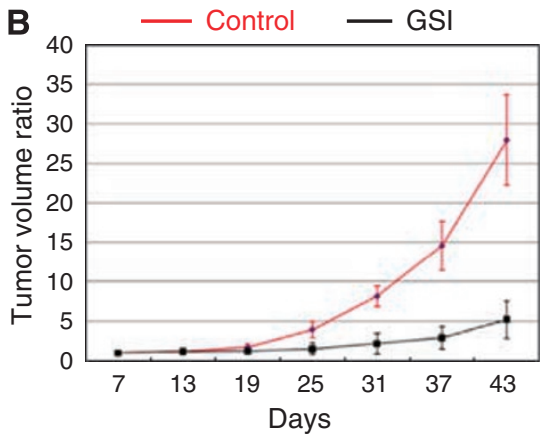

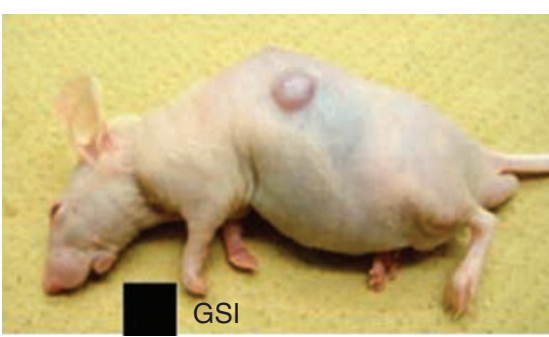

C

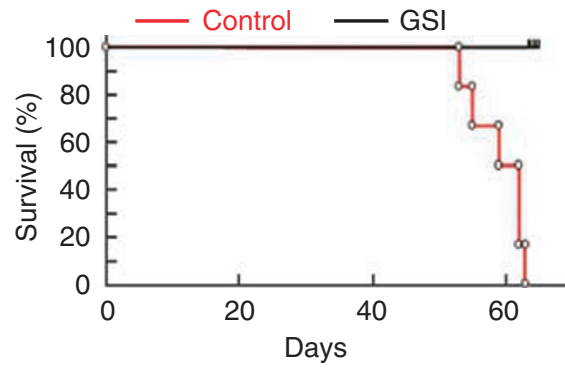

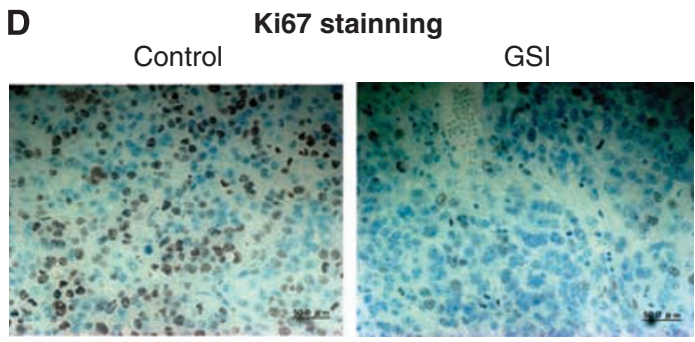

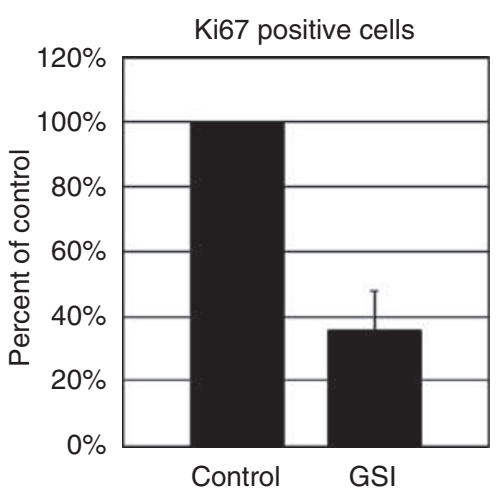

Figure 3 Notch pathway inhibition blocks osteosarcoma xenograft growth in vivo and prolongs survival. In all, $143 \mathrm{~B}$ cells $\left(\mid \times 10^{6}\right)$ were inoculated subcutaneously. Established I43B tumours were measured and then injected with $\gamma$-secretase inhibitor (GSI) or DMSO intraperitoneally. The tumour volume at day 7 was set at I, and tumour volumes at subsequent time points were calculated. $\gamma$-Secretase inhibitor significantly inhibited tumour growth at day 31 compared with DMSO. The following decreases in tumour volume were observed in GSI compared with DMSO treatment: day 25: $37.9 \%$; day 31: 26.3\%; day 37: 19.7\%; and day 43: I8.6\% (A and B). Kaplan-Meier survival curves from GSI treatment groups (black) and DMSO control (red). KaplanMeier analysis showed that GSI administration conferred a significant survival benefit $(\mathbf{C} ; n=6, P<0.05)$. Immunohistochemical examination of ki67 was carried out in xenograft tumours. Ki67 staining revealed that proliferation of osteosarcoma cells was decreased by GSI treatment. The number of Ki67positive cells was decreased to $36 \%$ of control revel by GSI administration at day 35 (D; error bar means s.d.).

amplicon of Notch1 in all specimens after 25-cycle reaction, although RT-PCR revealed that expression of Notch1 was decreased in osteosarcoma human specimens compared with normal bone.

To explore how Notch pathway activation contributes to osteosarcoma growth, we attempted to block the Notch pathway. Treatment of osteosarcoma cells with GSI to block Notch activation prevented osteosarcoma growth in vitro and in vivo. Our findings suggested an association between activation of Notch signalling and pro-oncogenic effects in the progression of human osteosarcoma. Although GSIs inhibit the cleavage and activation of Notch receptors (Deftos et al, 2000), they neither specifically inhibit Notch receptors nor inhibit cleavage of a number of other transmembrane proteins (Esler et al, 2000; Zhang et al, 2000; Ni et al, 2001; Marambaud et al, 2002). When we used CBF1 siRNA, a Notch cooperative transcriptional factor, siRNA also inhibited osteosarcoma growth effectively. These findings suggest that inhibition of Notch signalling prevents osteosarcoma growth. The role of GSIs in inhibiting the growth of osteosarcomas showed in this study is consistent with the findings of earlier studies of 
A

Cell proportion in
each cell cycle
\begin{tabular}{|c|c|c|c|}
\hline & G1 & S & G2 \\
\hline HOS & 54.6 & 11.3 & 29.9 \\
\hline $\begin{array}{c}\text { HOS+ } \\
\text { GSI }\end{array}$ & 64.8 & 4.8 & 24.4 \\
\hline
\end{tabular}

\begin{tabular}{|c|c|c|c|}
\hline $143 \mathrm{~B}$ & 39.8 & 17 & 41.3 \\
\hline $\begin{array}{c}143 \mathrm{~B}+ \\
\mathrm{GSI}\end{array}$ & 53.3 & 7.34 & 34.9 \\
\hline
\end{tabular}

B
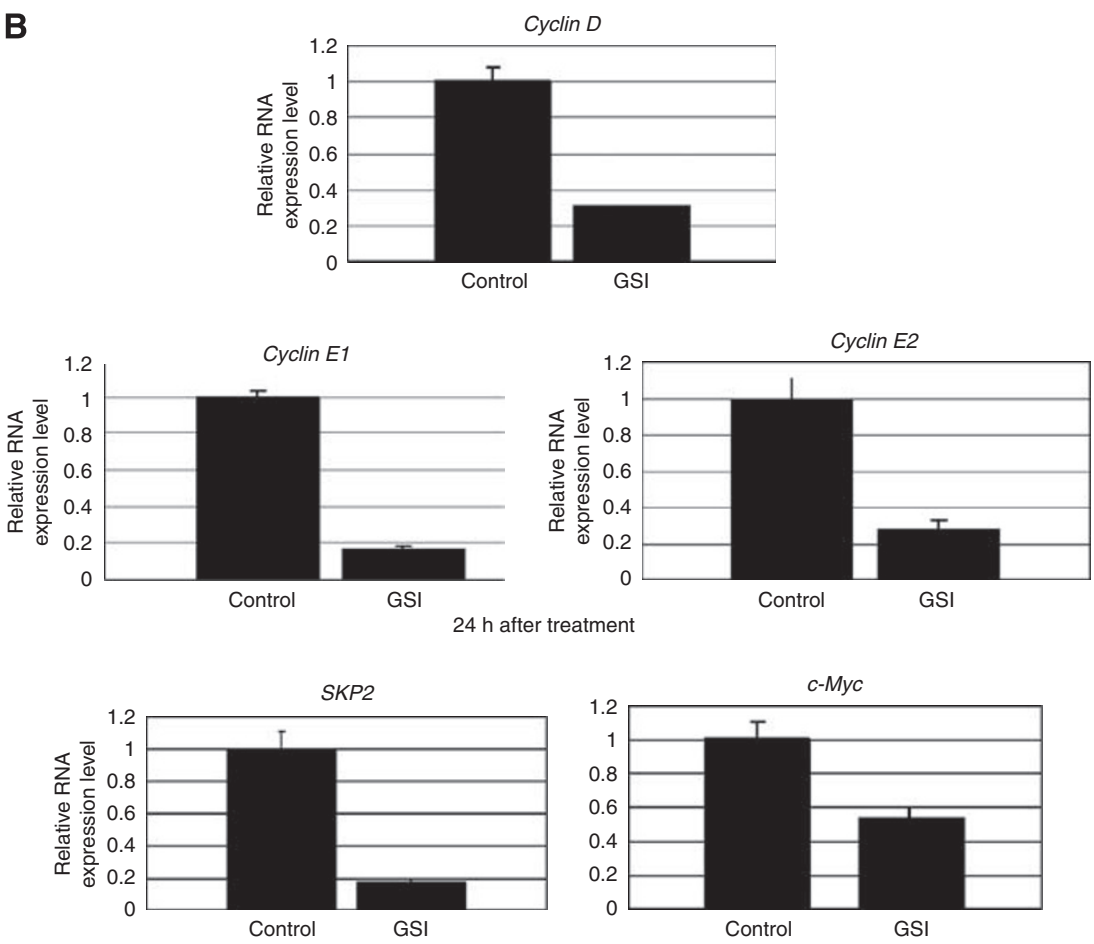

C

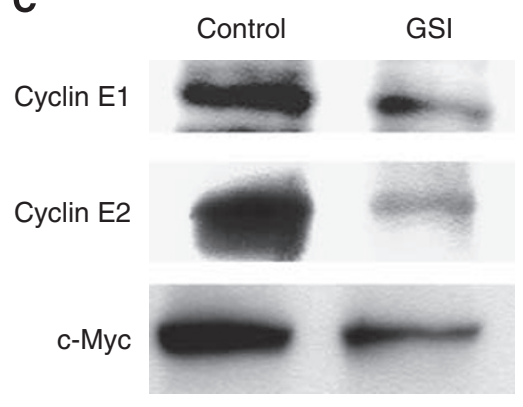

GSI

Control

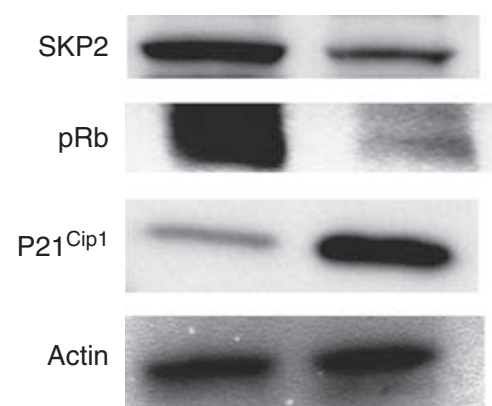

Figure 4 Notch pathway inhibition promotes GI arrest. HOS and I 43B cells were treated with $5 \mu \mathrm{M}$ GSI. After 48-h treatment, cells were collected and subjected to cell cycle analysis. When HOS cells were cultured without GSI, 54.6\% of cells were in GI phase. On the other hand, when cultured with GSI, $64.8 \%$ of cells were in GI phase. In the case of I43B cells cultured without GSI, 39.8\% of cells were in GI phase, whereas $53.3 \%$ of cells were in GI phase when treated with GSI (A). Real-time PCR was carried out to quantify mRNAs of cell cycle-related genes. A 24-h treatment with GSI reduced the levels of cyclin D, cyclin EI, E2, SKP2, and c-Myc transcription (error bar means s.d.; B). Western blot analysis of the levels of cell cycle-related genes. $48 \mathrm{~h}$ treatment with GSI reduced the levels of expression of cyclin EI, cyclin E2, c-Myc, pRb, and SKP2 proteins. Expression of P2I cip protein was upregulated by GSI treatment. The experiment was triplicate with similar results (C; GSI: $5 \mu \mathrm{M})$.

other malignancies (Pece et al, 2004; Curry et al, 2005; Park et al, 2008; Bin Hafeez et al, 2009; Meng et al, 2009; Real et al, 2009). Although oncoproteins are not usually tumorigenic when expressed alone, constitutively active NIC expression promotes papillary tumorigenesis (Klinakis et al, 2006). These findings showed that the Notch pathway is a strong activator of cell proliferation. Flow cytometry and ki67 staining showed that GSI promoted G1 arrest in osteosarcoma in vitro and inhibited tumour growth in vivo. We also found that GSI treatment regulated the expression of cell cycle regulators by Notch inhibition. Real-time PCR and western blot analysis revealed that cyclin D, E, SKP2, $\mathrm{c}-\mathrm{Myc}$, and pRB were downregulated, and $\mathrm{p} 21^{\mathrm{Cip} 1}$ was upregulated upon Notch inhibition with GSI. Cyclins D, E, pRb, c-Myc, and SKP2 have been reported to promote G1-S phase progression (Swanton, 2004; Hwang and Clurman, 2005). It has been reported that cyclins D, E, and SKP2 are direct targets of Notch (Leong and Karsan, 2006). In addition, SKP2 has been reported to be a component of ubiquitin E3 ligase regulating $G_{1} / S$ transition by degradation of $\mathrm{p}^{21^{\mathrm{cip} 1}}$ ( $\mathrm{Yu}$ et al, 1998). $\mathrm{p} 21^{\mathrm{cip1}}$ can bind to various CDKs, including cyclin D/CDK4, cyclin E, and cyclin A/CDK2, and inhibits their kinase activity. Suppression of the c-Myc oncogene induces cellular senescence and tumour regression in osteosarcoma (Wu et al, 2007). Our findings suggest that Notch signalling has the same effect against osteosarcoma as in other previously studied cancers. Recently, Zhang et al (2008) found, using soft agar assay and xenografts, that downregulation of Notch signalling by compound E suppressed osteosarcoma cell invasion. On the other hand, downregulation of Notch signalling by GSI (compound E) had no effect on cell proliferation or tumorigenesis. One possible explanation for this discrepancy in findings may be differences in cell lines used or GSI. We also carried out soft agar assay, and found that GSI effectively inhibited colony formation in soft agar assay (data not shown). Unfortunately, we have not yet prepared metastatic tumour models using human osteosarcoma 
cell lines, and have not yet examined the inhibitory effects on metastasis of GSI and CBF1 siRNA in vivo. Nonetheless, both of these studies provide independent support for the possibility that Notch pathway inhibition may be useful in treating osteosarcoma. It has been reported that GSI treatment induced apoptosis in Kaposi's sarcoma tumour cells (Curry et al, 2005). We carried out cell death detection assay, but could not detect the differences after GSI treatment in HOS and 143B HOS cell lines. These findings may have been due to differences in cell viability between osteosarcoma and Kaposi's sarcoma cell lines.

In conclusion, our findings show that the Notch signalling system is functionally activated in human osteosarcoma. This novel finding adds to the understanding of osteosarcoma and may be important in understanding the proliferation of osteosarcoma cells. Furthermore, the finding of growth inhibition by GSI, a
Notch inhibitor, suggests that inactivation of Notch may be a useful approach to the treatment of patients with osteosarcoma.

\section{ACKNOWLEDGEMENTS}

This study was supported by Grants-in-Aid for Scientific Research (B) 18390419 and (C) 19591725 (KAKENHI).

\section{Conflict of interest}

The authors declare no conflict of interest.

Supplementary Information accompanies the paper on British Journal of Cancer website (http://www.nature.com/bjc)

\section{REFERENCES}

Artavanis-Tsakonas S, Rand MD, Lake RJ (1999) Notch signaling: cell fate control and signal integration in development. Science 284: 770-776

Bettenhausen B, Hrabe de Angelis M, Simon D, Guenet JL, Gossler A (1995) Transient and restricted expression during mouse embryogenesis of Dll1, a murine gene closely related to Drosophila delta. Development 121: $2407-2418$

Bin Hafeez B, Adhami VM, Asim M, Siddiqui IA, Bhat KM, Zhong W, Saleem M, Din M, Setaluri V, Mukhtar H (2009) Targeted knockdown of Notch1 inhibits invasion of human prostate cancer cells concomitant with inhibition of matrix metalloproteinase- 9 and urokinase plasminogen activator. Clin Cancer Res 15: $452-459$

Curry CL, Reed LL, Golde TE, Miele L, Nickoloff BJ, Foreman KE (2005) Gamma secretase inhibitor blocks Notch activation and induces apoptosis in Kaposi's sarcoma tumor cells. Oncogene 24: 6333-6344

Dang TP, Gazdar AF, Virmani AK, Sepetavec T, Hande KR, Minna JD, Roberts JR, Carbone DP (2000) Chromosome 19 translocation, overexpression of Notch3, and human lung cancer. J Natl Cancer Inst 92: $1355-1357$

Davis RL, Turner DL (2001) Vertebrate hairy and Enhancer of split related proteins: transcriptional repressors regulating cellular differentiation and embryonic patterning. Oncogene 20: 8342-8357

De Strooper B, Annaert W, Cupers P, Saftig P, Craessaerts K, Mumm JS, Schroeter EH, Schrijvers V, Wolfe MS, Ray WJ, Goate A, Kopan R (1999) A presenilin-1-dependent gamma-secretase-like protease mediates release of Notch intracellular domain. Nature 398: 518-522

Deftos ML, Huang E, Ojala EW, Forbush KA, Bevan MJ (2000) Notch1 signaling promotes the maturation of CD4 and CD8 SP thymocytes. Immunity 13: $73-84$

Esler WP, Kimberly WT, Ostaszewski BL, Diehl TS, Moore CL, Tsai JY, Rahmati T, Xia W, Selkoe DJ, Wolfe MS (2000) Transition-state analogue inhibitors of gamma-secretase bind directly to presenilin-1. Nat Cell Biol 2: $428-434$

Fan X, Matsui W, Khaki L, Stearns D, Chun J, Li YM, Eberhart CG (2006) Notch pathway inhibition depletes stem-like cells and blocks engraftment in embryonal brain tumors. Cancer Res 66: 7445-7452

Gibbs Jr CP, Weber K, Scarborough MT (2002) Malignant bone tumors. Instr Course Lect 51: $413-428$

Grabher C, von Boehmer H, Look AT (2006) Notch 1 activation in the molecular pathogenesis of T-cell acute lymphoblastic leukaemia. Nat Rev Cancer 6: $347-359$

Horowitz JM, Park SH, Bogenmann E, Cheng JC, Yandell DW, Kaye FJ, Minna JD, Dryja TP, Weinberg RA (1990) Frequent inactivation of the retinoblastoma anti-oncogene is restricted to a subset of human tumor cells. Proc Natl Acad Sci USA 87: 2775-2779

Hwang HC, Clurman BE (2005) Cyclin E in normal and neoplastic cell cycles. Oncogene 24: 2776-2786

Igney $\mathrm{FH}, \mathrm{Krammer} \mathrm{PH}$ (2002) Death and anti-death: tumour resistance to apoptosis. Nat Rev Cancer 2: $277-288$

Jarriault S, Brou C, Logeat F, Schroeter EH, Kopan R, Israel A (1995) Signalling downstream of activated mammalian Notch. Nature 377: $355-358$

Klinakis A, Szabolcs M, Politi K, Kiaris H, Artavanis-Tsakonas S, Efstratiadis A (2006) Myc is a Notch1 transcriptional target and a requisite for Notch1-induced mammary tumorigenesis in mice. Proc Natl Acad Sci USA 103: 9262 -9267

Lafleur EA, Koshkina NV, Stewart J, Jia SF, Worth LL, Duan X, Kleinerman ES (2004) Increased Fas expression reduces the metastatic potential of human osteosarcoma cells. Clin Cancer Res 10: 8114-8119

Leong KG, Karsan A (2006) Recent insights into the role of Notch signaling in tumorigenesis. Blood 107: 2223-2233

Maier MM, Gessler M (2000) Comparative analysis of the human and mouse Heyl promoter: Hey genes are new Notch target genes. Biochem Biophys Res Commun 275: 652-660

Marambaud P, Shioi J, Serban G, Georgakopoulos A, Sarner S, Nagy V, Baki L, Wen P, Efthimiopoulos S, Shao Z, Wisniewski T, Robakis NK (2002) A presenilin-1/gamma-secretase cleavage releases the E-cadherin intracellular domain and regulates disassembly of adherens junctions. EMBO J 21: $1948-1956$

Meng RD, Shelton CC, Li YM, Qin LX, Notterman D, Paty PB, Schwartz GK (2009) Gamma-secretase inhibitors abrogate oxaliplatin-induced activation of the Notch-1 signaling pathway in colon cancer cells resulting in enhanced chemosensitivity. Cancer Res 69: 573-582

Miyamoto Y, Maitra A, Ghosh B, Zechner U, Argani P, Iacobuzio-Donahue CA, Sriuranpong V, Iso T, Meszoely IM, Wolfe MS, Hruban RH, Ball DW, Schmid RM, Leach SD (2003) Notch mediates TGF alpha-induced changes in epithelial differentiation during pancreatic tumorigenesis. Cancer Cell 3: $565-576$

Ni CY, Murphy MP, Golde TE, Carpenter G (2001) Gamma-secretase cleavage and nuclear localization of ErbB-4 receptor tyrosine kinase. Science 294: 2179-2181

Oda T, Elkahloun AG, Pike BL, Okajima K, Krantz ID, Genin A, Piccoli DA, Meltzer PS, Spinner NB, Collins FS, Chandrasekharappa SC (1997) Mutations in the human Jagged1 gene are responsible for Alagille syndrome. Nat Genet 16: 235-242

Park JT, Li M, Nakayama K, Mao TL, Davidson B, Zhang Z, Kurman RJ, Eberhart CG, Shih Ie M, Wang TL (2006) Notch3 gene amplification in ovarian cancer. Cancer Res 66: 6312-6318

Park JT, Shih Ie M, Wang TL (2008) Identification of Pbx1, a potential oncogene, as a Notch3 target gene in ovarian cancer. Cancer Res 68: $8852-8860$

Pece S, Serresi M, Santolini E, Capra M, Hulleman E, Galimberti V, Zurrida S, Maisonneuve P, Viale G, Di Fiore PP (2004) Loss of negative regulation by Numb over Notch is relevant to human breast carcinogenesis. J Cell Biol 167: $215-221$

Politi K, Feirt N, Kitajewski J (2004) Notch in mammary gland development and breast cancer. Semin Cancer Biol 14: $341-347$

Radtke F, Raj K (2003) The role of Notch in tumorigenesis: oncogene or tumour suppressor? Nat Rev Cancer 3: 756-767

Real PJ, Tosello V, Palomero T, Castillo M, Hernando E, de Stanchina E, Sulis ML, Barnes K, Sawai C, Homminga I, Meijerink J, Aifantis I, Basso G, Cordon-Cardo C, Ai W, Ferrando A (2009) Gamma-secretase inhibitors reverse glucocorticoid resistance in $\mathrm{T}$ cell acute lymphoblastic leukemia. Nat Med 15: 50-58

Swanton C (2004) Cell-cycle targeted therapies. Lancet Oncol 5: 27-36 van Es JH, van Gijn ME, Riccio O, van den Born M, Vooijs M, Begthel H, Cozijnsen M, Robine S, Winton DJ, Radtke F, Clevers H (2005) Notch/ 
gamma-secretase inhibition turns proliferative cells in intestinal crypts and adenomas into goblet cells. Nature 435: 959-963

Weng AP, Aster JC (2004) Multiple niches for Notch in cancer: context is everything. Curr Opin Genet Dev 14: 48-54

Weng AP, Ferrando AA, Lee W, Morris IV JP, Silverman LB, Sanchez-Irizarry C, Blacklow SC, Look AT, Aster JC (2004) Activating mutations of NOTCH1 in human $\mathrm{T}$ cell acute lymphoblastic leukemia. Science 306: 269-271

Wu CH, van Riggelen J, Yetil A, Fan AC, Bachireddy P, Felsher DW (2007) Cellular senescence is an important mechanism of tumor regression upon c-Myc inactivation. Proc Natl Acad Sci USA 104: 13028-13033
Yu ZK, Gervais JL, Zhang H (1998) Human CUL-1 associates with the SKP1/SKP2 complex and regulates p21(CIP1/WAF1) and cyclin D proteins. Proc Natl Acad Sci USA 95: 11324-11329

Zhang P, Yang Y, Zweidler-McKay PA, Hughes DP (2008) Critical role of notch signaling in osteosarcoma invasion and metastasis. Clin Cancer Res 14: $2962-2969$

Zhang Z, Nadeau P, Song W, Donoviel D, Yuan M, Bernstein A, Yankner BA (2000) Presenilins are required for gamma-secretase cleavage of beta-APP and transmembrane cleavage of Notch-1. Nat Cell Biol 2: $463-465$ 